\title{
The Doctrine of Imago Dei and the Challenge of Euthanasia
}

\begin{abstract}
The issue of acceptance of euthanasia (assisted death) in the face of affirming human dignity as preservation of the image of God in human beings is fiercely debated over the world. Different (Christian and non-Christian) ethicists hold different positions in the debate. Some of the key questions in the debate include how moral is it to legalize euthanasia in the face of the doctrine of Imago Dei? Should the quality of a person's life overrule the sanctity of human life? This paper examines the arguments for and against the legalization of euthanasia and then considers how the doctrine of the imago Dei should inform one's decision to accept or reject euthanasia. With the African religio-cultural worldview as a contextual framework, the study contends that even though the preservation of physical life is not the ultimate goal of Christianity (since physical death is inevitable), human life should not be shortened deliberately for any reason. Therefore, it is morally wrong to take anybody's life under any circumstance.
\end{abstract}

Keywords: Death, Euthanasia, Human Dignity, Imago Dei, Legalization

\author{
ISAAC BOAHENG ${ }^{1}$ \\ ${ }^{1}$ Isaac Boaheng, an ordained minister \\ of the Methodist Church Ghana, \\ currently serves as a Translator for \\ the Bible Society of Ghana. Isaac \\ serves as a circuit minister for the \\ Nkwabeng circuit of the Sunyani \\ Diocese. He holds a Master of \\ Divinity degree from the Trinity \\ Theological Seminary and has \\ research interest in Religion Studies, \\ Public Theology, Biblical Studies, and \\ African Christianity. \\ Email: revisaacboaheng@gmail.com \\ Manuscript \\ Received 5th March 2020, \\ Accepted 1st June 2020, \\ Published online 22nd June 2020.
}

\section{INTRODUCTION}

Etymologically, euthanasia derives from the Greek words eu ("good") and thanatos ("death"); therefore, the term euthanasia includes notions such as "good death", "gentle death" or "easy death." Based on its etymological meaning, different scholars have expressed different opinions about what euthanasia really means. For example, Wayne Grudem defines it euthanasia as "the act of intentionally ending the life of a person who is elderly, terminally ill, or suffering from some incurable injury or disease." 3 John Keown widens his definition to include both "the intentional termination of the patient's life by an act such as a lethal injection (and) ...the intentional termination of life by an omission." ${ }^{.4}$ In this sense a physician administers euthanasia if he or she intends to kill a patient by switching off a ventilator or by withdrawing a patient's feeding tube. Francis Beckwith and Norman L. Geisler describe euthanasia as "the intentional taking of a human life for some good purpose, such as to relieve suffering or pain." ${ }^{5}$ For Ferdinand Sakali euthanasia is the "killing of a human being on the grounds that he is better off dead." ${ }^{6}$ From these scholarly definitions comes the researcher's working definition: Euthanasia is the medical assistance given to a person who is suffering unbearably as a result of a terminal illness to die at his or her (the patient's) own considered and persistent request so that the person can have a "good death." In other words, what this study considers as euthanasia is the deliberate action taken to end the life of a terminally-ill person upon the person's request or because others (such as family members or physicians) consider such action to be appropriate in this situation at hand.

\footnotetext{
2 Wayne Grudem, Christian Ethics: An Introduction to Biblical Moral Reasoning (Wheaton, IL: Crossway, 2018), np. Pdf version; see also J. Donald Boudreau and Margaret A Somerville, "Euthanasia and Assisted Suicide: A Physician's and Ethicist's Perspectives" in Medicolegal and Bioethics 2014 (4): 1-12 at 2.

Grudem, Christian Ethics, np.

4 John Keown as quoted by Ferdinand Sakali, "The Contemporary Euthanasia Debate In The Light of African World View And Ethics" in SEGi Review Vol. 6, (2013), 5-15:6.

Francis Beckwith and Norman L. Geisler, Matters of Life and Death (Grand Rapids, MI: Baker Book House, 1991), 141.

Sakali, "The Contemporary Euthanasia Debate", 5.
} 
It is important to distinguish between "killing" (that is, "actively doing something to a patient that hastens or causes his or her death" and "letting die" (that is, "passively allowing someone to die from other causes, without interfering with that process"). ${ }^{7}$ In the first instance death is caused by the action taken by another person but in the second instance death results from disease, injury, or aging process. From the working definition of this paper and the distinction just made above, it should be noted that not all forms of direct actions that lead to a patient's death can be classified as euthanasia. Assume that a person takes Artesunate Amodiaquine at home and later visits the hospital for treatment. The physician who is not aware that the patient had taken an earlier dose of Artesunate Amodiaquine then gives the patient another dose of the same drug and the patient dies due to overdose of the drug. Such a death does not qualify to be called euthanasia because it was not the intention of the physician to cause death. Also, death occurring from negligence or lack of necessary medicines or medical equipment cannot be categorized as euthanasia. Furthermore, it is not every act of withdrawing or withholding treatment that qualifies as a case of euthanasia. For example, euthanasia does not occur if stopping treatments that are not helpful to the patient leads to death. For a death to be regarded as euthanasia there must have been a deliberate attempt to take the person's life or to let him or her die.

The acceptability of euthanasia in the face of affirming human dignity as preservation of the image of God in human beings is a subject that has generated heated arguments for a long time. Euthanasia is deeply controversial, for moral and practical reasons. From the moral viewpoint, euthanasia seems to contradict one of the most basic principles of morality - that is, killing is wrong. ${ }^{8}$ Viewed from a secular perspective, the practice of euthanasia seems to uphold the quality of life principle. Euthanasia therefore creates an inherent tension between respecting individual autonomy and relieving people from unbearable suffering while still protecting the principle of sanctity of human life. The sanctity of life argument is rooted in the doctrine of imago Dei, the fact that God created human beings in his own image. This paper examines the arguments for and against the practice of euthanasia in the light of the doctrine of the imago Dei. The main contention of the study is that even though the preservation of physical life is not the ultimate goal of Christianity (since physical death is inevitable), human life should not be shortened for any reason. Therefore, it is morally wrong to take anybody's life for any reason.

\section{The Euthanasia Debate}

This section deals with key issues in the debate over the legalization of euthanasia. The limitations of time and space will not allow the paper to examine all expects of the debate and so only a highlight of key areas of the debate is offered here. Based on the concept of the autonomy of patients, the pro-euthanasia movement argues that "human persons are free and autonomous, and therefore may choose a peaceful death rather than bearing the indignity of a life no longer worth living." The word autonomy derives from the Greek auto meaning "self" and nomos meaning "law" or "rule" and therefore, to be autonomous means "to be a law unto oneself." 10 According to advocates of euthanasia, human dignity encompasses self-determination and the ability to make autonomous or self-determined choices. ${ }^{11}$ The autonomy of a patient also means he or she has the right to refuse treatment or certain medications. Respect for individual autonomy should allow patients the opportunity to choose euthanasia as an alternative to becoming dependent upon medical carergivers and burdensome to family and society. ${ }^{12}$

Arguing in favour of this position, Ronald Dworkin states, "Making someone die in a way that others approve, but he believes is a horrifying contradiction of his life, is a devastating, odious form of tyranny."13 Dworkin's point is that it is the absolute right of the suffering patient to make a decision to live or to die and the legalization of euthanasia will ensure that this freedom to choose to end one's own life is enjoyed. Another important note from Dworkin's assertion is that denying a suffering person the right to choose to die is a wicked thing to do.

In response to the above pro-euthanasia argument is the anti-euthanasia contention that legalizing euthanasia has the tendency of coercion and loss of autonomy because once there is public recognition that euthanasia is legally available, there is the high likelihood that people would be robbed of their autonomy. ${ }^{14}$ It is in this light that Ezekiel Emmanuel writes that, "Broad legalization of physician-assisted suicide and euthanasia would have the paradoxical effect of making patients seem to be responsible for their own suffering." ${ }^{15}$ Emmanuel further states that "Rather than being seen primarily as the victims of pain and suffering caused by disease, patients would be seen as having the power to end their suffering by agreeing to an injection or taking some pills; refusing would mean that living through the

\footnotetext{
Grudem, Christian Ethics, np. This paper is more of the former, active euthanasia.

Norman L. Geisler, Christian Ethics: Contemporary Issues and Option, Second edition (Grand Rapids: Baker Academic, 2010$), 169$.

Joseph Pakhu, "Debate on Euthanasia (Pros and Cons)", (Unpublished MTh Thesis: Universidade Católica Portuguesa, 2015), 16

Robert C. Sproul, Chosen by God (Illinois: Tyndale Publishers Inc., 1986), 42.

Pakhu, "Debate on Euthanasia," 17.

Geisler, Christian Ethics, 167.

James D. Torr (ed), Euthanasia: Opposing Viewpoints (California: Greenhaven Press, Inc., 2000), 71. (pdf)

Geisler, Christian Ethics, 169.

As cited in Torr (ed), Euthanasia: Opposing Viewpoints, 83.
} 
pain was the patient's decision, the patient's responsibility." ${ }^{16}$ The point is that, if euthanasia is legalized, vulnerable patients could feel an obligation to accept it in order to reduce the burden on their families and their caretakers. In such a desperate situation, it is possible that even when patients do not want to die, care-givers might not want to care for them anymore. Furthermore, the argument from autonomy undermines God's sovereignty and must be rejected. ${ }^{17}$ Logically, it is impossible for a sovereign God to co-exist with an autonomous creature at the same time. ${ }^{18}$ Human autonomy is to be exercised within God's sovereignty. ${ }^{19}$ Humans have freedom; but this freedom has a limit. Human freedom is limited by God's sovereignty.

The argument that patients have the right to die (coming from the right-to-die movement) has been opposed by an organization called right-to-life. One of the advocates of the right-to-life group, James Bopp argues that "The principal responsibility of society and government is to protect life, so it ought not to be legalizing the killing of one person by another." ${ }^{20}$ If a physician can take the very life that his profession obliges him to preserve, then there will be ambiguity in his or her work and the physician's special role will be destroyed eventually. ${ }^{21}$ At the same time, it is possible that a "right to die" might be interpreted as a "duty to die" (or "natural right") by others, particularly the vulnerable. ${ }^{22}$ More so, the assumption that patients should have a right to die would impose on doctors a duty to kill and consequently restrict the autonomy of the doctor. Eventually, the relationship between the physician and the patient will be destroyed and patients will lose confidence in their care-givers..$^{23}$

The second major argument of the pro-euthanasia movement is that the legalization of euthanasia will help patients to avoid unnecessary and inevitable suffering. ${ }^{24}$ The pro-euthanasia movement argues that mercy and compassion demands that patients with terminal illnesses or in hopeless condition be allowed to have a good and peaceful death rather than to suffer, without any chance of relief or recovery. Advocates of this position consider euthanasia as an act of mercy and love. According to Derek Humphry, "Helping another to die in carefully considered circumstances is part of good medicine and also demonstrates a caring society that offers euthanasia to hopelessly sick persons as an act of love." ${ }^{25}$ Ethicist Dan Brock argues that "Euthanasia should be available as a compassionate means of ending the pain and suffering of those for whom the termination of life support or the refusal of aggressive treatment does not end their lives." ${ }^{26}$ Humphry's and Brock's point is that it as inhumane and cruel to make a suffering person, whose death is inevitable and imminent, live longer than he or she desires. It is in this light that the term euthanasia is sometimes referred to as "mercy killing." At the point when death is imminent, advocates of euthanasia consider allowing a person to "die with dignity" as kinder than forcing him or her to continue his or her life with suffering. ${ }^{27}$

Countering this argument, the anti-euthanasia group maintains that the mercy of euthanasia is a false or perverted one. ${ }^{28}$ Killing someone in pain to relief the person of his or her pain is not a loving and compassionate thing to do. John Paul II, arguing against the legalization of euthanasia, says, "True compassion leads to sharing another's pain but it does not kill the person whose suffering we cannot bear." ${ }^{29}$ Killing a suffering person, it is argued, does not in any way eradicate human misery; rather, it has a high tendency of increasing misery. ${ }^{30}$ Euthanasia becomes more perverse when sanctioned by the patient's family who are expected to treat their relative with true love, compassion and patience.$^{31}$ Euthanasia, therefore, may deprive the sick of the family companionship, sympathy and support in their difficult moments. Moreover, even if euthanasia is capable of avoiding more pain and suffering, it is a cruel act which cannot be justified because, as Geisler argues, the end does not justify all means; the end justifies only good means. ${ }^{32}$ Since killing a person is not a good act (Exod. 20:13), it cannot be considered as a good thing to do no matter the end result.

\footnotetext{
16 As cited in Torr (ed), Euthanasia: Opposing Viewpoints, 83.

Geisler, Christian Ethics, 169.

Sproul, Chosen by God, 42.

19 For an exhaustive treatment of the relationship between God's sovereignty and human autonomy consult Isaac Boaheng, Exploring the Relationship Between Divine Sovereignty and Human Responsibility in Relation to God's Plan of Salvation (Master of Divinity Thesis, Trinity Theological Seminary, 2016).

20 Bopp as cited by Pakhu, "Debate on Euthanasia," 28.

Pakhu, "Debate on Euthanasia," 28.

Geisler, Christian Ethics, 169.

Pakhu, "Debate on Euthanasia," 28.

Geisler, Christian Ethics, 165-166.

Derek Humphry, Dying with Dignity: Understanding Euthanasia (New York: Carol Publishing Group, 1992), 91.

As cited by Pakhu, "Debate on Euthanasia," 31.

Michael Tooley, "Euthanasia and Assisted Suicide" in Raymond G. Frey and C. H. Wellman (eds.), A Companion to Applied Ethics (Malden: Blackwell Publishing Ltd., 2003), 329.

28 Pakhu, "Debate on Euthanasia," 34.

29 As cited by Pakhu, "Debate on Euthanasia," 34.

- Geisler, Christian Ethics, 166.

Pakhu, "Debate on Euthanasia," 34-35.

32 Geisler, Christian Ethics, 166.
} 
Again, poor decision-making by the sufferer or others may lead to inappropriate euthanasia. A person's expression of a desire to end his or her life may be informed by a state of depression or severe pain, conditions which may be relieved by proper treatment. If given such treatment, the person may no longer desire to die. A person's capacity to make an informed and competent decision may be difficult to ascertain and thus, the request by a patient for euthanasia may be inappropriate (even if euthanasia were ethical). The most important point in this regard is that pain and suffering are not sufficient reasons to disobey the moral command against murder.

Instead of advocating for euthanasia due to pain and suffering, it is argued, one should rather consider medical ways of alleviating pains and suffering which modern technology in health provides. Nearly all pain can be relieved through alternative care such as palliative care and hospices. Palliative care refers to treatment and care of a terminally ill patient with the aim of relieving physical, emotional and psycho-social suffering and of maintaining personal hygiene. ${ }^{33}$ Hospice care refers to "a type of care and philosophy of care that focuses on the palliation of a chronically ill, terminally ill or seriously ill patient's pain and symptoms, and attending to their emotional and spiritual needs." ${ }^{\prime 34}$ It is argued that because of advanced medical treatment, through pain control and palliative care there is no need for a terminally ill person to have to confront unbearable pain and suffering that will lead to considering euthanasia as an option.

In response to the anti-euthanasia movement's argument that pain and sufferings can be eliminated by modern medical technology, it has been argued that medical technology cannot offer alleviation of physical pain to many terminal patients and is such conditions euthanasia is required to prevent people who are about to die from being trapped in life-support machines, thereby prolonging their pain..$^{35}$ The researcher believes that not all pains can be alleviated through medical means and therefore the anti-euthanasia argument in this regard (outlined in the previous paragraph) seems less convincing. That however, in the researcher's view, does not also justify the pro-euthanasia movement's demand for the legalization of euthanasia.

Thirdly, the pro-euthanasia group further contends that the legalization of euthanasia is required to allow the individual to value "quality of life" (the usefulness of one's life to him/herself and to the community) over "sanctity of life" (intrinsic value of one's life as God's sacred gift). ${ }^{36}$ It is argued that when life is devoid of its human quality (such as the ability to communicate with others, being conscious and responsive to surrounding environments), it ceases to be worth living and the person involved must not be allowed to live any longer. ${ }^{37}$ In other words, a person who is completely dependent on others, due to sickness, have no quality of life and, may not be allowed to live any longer. When there is suffering, pain and terminal illness or sickness that offers no real hope for full recovery, a person's quality of life is so low that she is better off dead than alive ${ }^{38}$ For a patient whose life has no value, euthanasia is a beneficial act rather than a harmful act. Therefore, at a point when a person's life depends, for example, on drugs which could reduce consciousness and control, it will be in the interest of most of such patients to request an end to life, legalized euthanasia becomes the best personally-chosen option to end the patient's life, without placing other people in legal difficulty. ${ }^{39}$

In opposition to this argument is the contention that euthanasia cheapens the sanctity or value of life ${ }^{40}$ It is argued that life is inviolably sacred and nothing can justify the terminating of human life including intolerable suffering, therefore, legalizing euthanasia to make taking people's life legal is wrong. ${ }^{41}$ The anti-euthanasia group hold that no one has the right to say that the life of a patient is not worth living and must be terminated because of the low quality of life. ${ }^{42}$ Geisler concludes as follows "When we do not respect the dying, it affects our attitude toward the living. Human life is a continuous and continual web... Hence, what affects one member of the race [no matter his or her health status] affects all." ${ }^{\prime 3}$

Another pro-euthanasia argument is that euthanasia should be allowed in order to reduce reliance on life support systems and/or modern medical knowledge, and hence avoid avoidable high cost. ${ }^{44}$ Extending a person's life artificially is possible because modern hospitals are equipped with cardiopulmonary resuscitation devices and technologies which can re-start and maintain heart and lung functions when the body fails to breathe and circulate blood on its own. ${ }^{45}$ Life

\footnotetext{
World Health Organization, Planning and Implementing Palliative Care Services: A Guide for

Programme Managers (Geneva: WHO Press, 2016), 9. Pdf version

34 Sharon Chaiklin and Hilda Wengrower (eds.), The Art and Science of Dance/Movement Therapy: Life Is Dance 2nd edition (London: Routledge, 2016), 185.

35 Michael Manning, Euthanasia and Physician-Assisted Suicide: Killing or Caring? (New York: Paulist Press, 1998$), 40$.

36 Keown, Euthanasia, Ethics and Public Policy, 43-44.

Pakhu, Debate on Euthanasia, 54.

38 Keown, Euthanasia, Ethics and Public Policy, 43-44.

39 See Pakhu, "Debate on Euthanasia," 55-57.

40 Geisler, Christian Ethic, 174.

41 Megan-Jane Johnstone, Bioethics: A Nursing Perspective 2nd edition (Australia: Southwood Press, 1994), 339.

42 Pakhu, Debate on Euthanasia, 58.

43 Geisler, Christian Ethic, 174.

${ }_{44}$ Ibid., 166

45 Samuel Waje Kunhiyop, African Christian Ethics (Nairobi: WordAlive Publishers, 2008), 346.
} 
support technologies introduced in the medical field have now produced a new kind of patient- one whose brain has ceased to function, but whose heart and lungs continue to work (artificially). Therefore, if one really wants prolong a patient's life artificially, it is possible. However, these modern health facilities may be very expensive to apply. ${ }^{46}$ The cost of health care has increased greatly and continues to increase every day. Therefore, it is argued that, there is no need to make use of expensive medical devices in situations where the only positive outcome is the temporary extension of life, without improvement in quality of life or without any hope of recovery. ${ }^{47}$ There is no need, say advocates of euthanasia, for a family to go bankrupt by paying for the artificial extension of a member's life without any hope of recovery.

The anti-euthanasia response to the above argument is that once suffering persons are able to choose to die, it will lead to a reduction in the motivation of financial sources to fund research, provision of caring facilities, training of care-givers, and maintenance of support systems. ${ }^{48}$ Similarly, when euthanasia is legalized the need for physicians to fight against the deadly disease might reduce, thereby leading to the abandonment of patients with extremely difficult health problems. ${ }^{49}$ It is maintained that it is God who has given humans the knowledge to develop technology that could ensure the extension of life through the support of such equipment as cardiopulmonary resuscitation and dialysis; therefore, there is nothing wrong applying these devices to improve the health of terminally-ill patients. More so, legalizing euthanasia has the tendency of reducing efforts in diagnosis, treatment, and care because such efforts are likely to go waste if euthanasia is legalized.

In addition, it is a loving thing to use wealth to save a person's life if possible. Grudem argues that proeuthanasia argument based on cost of medical care fails because the lack of money cannot be a justification for taking another person's life. ${ }^{50}$ Grudem however adds that for terminally-ill patients who have no reasonable human hope of recovery, "letting die" may be the right decision to take depending on the patient's desire and the available financial resources to cater for him or her. ${ }^{51} \mathrm{He}$ maintains that the situation of "letting die" is however different from actively killing another due to the decision of the society to spend less on caring for old, sick people. ${ }^{52}$

Geisler contends that life is priceless and so if life should be preserved only when one we can afford it. ${ }^{53}$ He maintains further than no amount of material wealth can match the spiritual worth of the life of one created in the image of God and that just one human life is more valuable than the entire world (Mark 8:36; Matt. 6:26). ${ }^{54} \mathrm{He}$ finds the pro-euthanasia argument that life may be shortened for the relief of financial burden as materialistic and hence concludes that "to argue that we should take life in order to save money is a distorted and materialist view of human life. ${ }^{" 55}$

Having offered some key points in favor and against the legalization of euthanasia, the study now moves on to consider the doctrine of imago Dei in accordance with the biblical data and church tradition available on it.

\section{The doctrine of Imago Dei}

The Bible makes it clear that humans were created in the image of God (Gen. 1:26-27). This fact that humans are God's image bearers is referred to as the doctrine imago Dei. The doctrine of the imago Dei informs the nature of humanity as individuals and as a corporate entity and serves as a key basis for the Christian valuation of human life. ${ }^{56}$ It therefore defines the purpose of humans both now and in the world to come. It forms a key part in the foundation of Christian anthropology and informs the Christian theological understanding of human-divine and human-human relationships.

There are a number of Biblical texts that teach this topic, including, Genesis 1:26-27, 5:1;9:6 in the Old Testament and 1 Corinthians 11:7 and James 3:9 in the New Testament. There are also a few apocryphal or deuterocanonical references (Wisdom of Solomon 2:23; Sirach 17:3; and 2 Esdras 8:44) that point to the idea that humans are made in God's image. Of these, Genesis 1:26-27 is the most important with respect to the biblical doctrine of imago Dei. It is only in this verse that one finds both the key terms demuth (likeness) and tselem (image); these terms correspond to the Greek words eikon (image) and homoiosis (likeness). Genesis 1:26-27 portrays God as resolving with foresight and planning the creation of humans. His participation in this divine act is more personal and intimate. Gerhard von Rad

46 Kunhiyop, African Christian Ethics, 346.

47 Geisler, Christian Ethics, 166.

48 See University of Western Ontario, The Canadian Journal of Law and Jurisprudence, Volumes 1-2 (Ontario: University of Western Ontario, 1989), 49. See also “Anti-euthanasia arguments" http://www.bbc.co.uk/ethics/euthanasia/against/against_1.shtml (Accessed 28th May, 2020)

49 See University of Western Ontario, The Canadian Journal of Law and Jurisprudence, 49. See also "Anti-euthanasia arguments"

50 Grudem, Christian Ethics, np.

51 Ibid.

52 Ibid.

53 Geisler, Christian Ethics, 168.

${ }_{54}$ Ibid.

55 Ibid.

56 C. F. C. Henry, "Image of God" in Evangelical Dictionary of Theology (2nd Edition) edited by Walter A. Elwell (Grand Rapid, MI: Baker Publishing Group, 2001), 593. 
declares that the imago Dei makes humans the the apex, the climax, the goal of all creation. ${ }^{57}$

What do scholars mean when they say God created humanity in his own image? The next section takes care of this question.

\section{Views of the Image of God in Human}

The ambiguous nature of the biblical concept of the image of God has led to various interpretations. Theories that attempt to define the nature of the imago Dei fall into three general categories..$^{58}$

\section{The Substantive View of the Imago Dei}

The first is the substantive view which seeks to identify some human quality or characteristic as that which defines the image of God in man. ${ }^{59}$ Some of the human qualities that scholars have suggested through the centuries are conscience, aesthetic sense, dominion, emotional capacities, original righteousness, spiritual awareness, immortality, freedom, personhood, and moral capacity as other substantial characteristics of human nature that form part of the imago Dei. This view, according Erickson, may be the result of the literal interpretation of the words tselem as statue or form so that Genesis 1:26 will mean "Let us make humans who look like us." ${ }^{60}$ Noting the early prevalence of this view Louis Berkhof states, "the early Church Fathers were quite agreed that the image of God in man consisted primarily in man's rational and moral characteristics, and in his capacity for holiness; but some were inclined to include bodily traits." Patristic and Medieval theologians emphasised reason as the main "substance" of the image of God. David Cairns has observed "In all the Christian writers up to Aquinas we find the image of God conceived of as man's power to reason." 62

Many theologians equate imago Dei to reason due to Philo's contention that the mind (nous) constituted the image, and Aristotle's view that human beings were rational animals.$^{63}$ Therefore, many have traced this emphasis upon reason back to the influence of Greek philosophy and Gnosticism. ${ }^{64}$ Major proponents of the substantive view are Justin Martyr, the above-mentioned Irenaeus, Gregory of Nyssa, Augustine, Thomas Aquinas, Martin Luther, John Calvin, Carl F. H. Henry, and Walther Eichrodt. ${ }^{65}$

The substantive view is narrowed to one aspect of human nature; intellect. ${ }^{66}$ The difficulty with this view is that if God's image is a function of one's intellect then the image of God varies from person to person. ${ }^{67}$ This would mean that the more intelligent a person is the greater the extent of God's image he/she possesses, which should not be the case. David Tarus, paraphrasing Reynolds, also notes that the "emphasis on the inward possessions or inner capacities of human nature also denigrates the body and it demeans humans who might not be able to live up to the desired capacities such as persons with disabilities." ${ }^{68}$ More so, it fails to give adequate explanation to what sin did to the image.

\section{The Relational View of the Imago Dei}

The relational view on the other hand holds that the image is in relational terms rather than something resident within human nature. ${ }^{69}$ Thus, humans can be said to be in the image of God when standing in a particular relationship with God. This view is more popular among modern theologians of which Reformed theologians are chief representatives. ${ }^{70}$ Martin Luther, without completely breaking free from his predecessors who defined image in terms of rationality, argued that the image of God was the original holiness that human beings possessed before the fall. ${ }^{71}$ For Luther, though reason is important, the relationship with God is of supreme significance. ${ }^{72}$ Brunner distinguishes two aspects of the image: the formal aspect referring to "that which makes a person human, distinguishing the human from the animal, as a rational

\footnotetext{
37 Gerhard von Rad, Genesis (Philadelphia: Westminster Press, 1972), 57.

3 Millard J. Erickson, Christian Theology 2nd edition (Grand Rapids, MI: Bake Academic, 1998), 520-529.

59 Erickson, Christian Theology, 521.

${ }^{60}$ Ibid.

${ }^{61}$ Louis Berkhof, Systematic Theology (Edinburg: Banner of Truth, 2000), 202.

62 David Cairns, The Image of God in Man (London: SCM, 1953), 110.

63 See Erickson, Christian Theology, 521.

${ }_{64}$ Gordon R. Lewis and Bruce A. Demarest, Integrative Theology: Historical, Biblical, Systematic, Apologetic, Practical (Grand Rapids: Zondervan, 1996), 124.

${ }_{65}$ James R. Beck and Bruce Demarest, The Human Person in Theology and Psychology: A Biblical Anthropology for the Twenty-First Century (Grand Rapids: Kregel Publications, 2005), 145-47.

${ }_{66}$ Erickson, Christian Theology, 521-522.

67 Ibid., 531.

68 David Tarus "Imago Dei in Christian Theology: The Various Approaches" Online International Journal of Arts and Humanities Volume 5 (2016) 18-25:19.

69 Erickson, Christian Theology, 523-524.

70 Lewis and Demarest, Integrative Theology, 127.

71 Ibid.

72 Ibid.
} 
being, responsible and free" and materials aspect which refers to "the act of response, the relationship with God." 73 Barth sees the image of God as consisting of relationships that may be vertical (man to God) as well as horizontal (man to woman in marriage, or man to man in society). Barth explains, "it is essential and natural to man not only to be with God but also, on the horizontal level and in analogy with this togetherness with God, to be with his fellow-man: not in isolation ... there can be no I without the Thou, no man without the fellow-man, any more than there can be any man without God." 74 Again, Barth notes, "The command of God comes to man and woman in the relationship and order in which God created them to be together as His image." ${ }^{75} \mathrm{He}$ further argues that the image is also found in humankind being created male and female (Gen. 1:27 and 5:1-2). ${ }^{76}$

As a way of evaluation, it can be said that the relational view does well in noting that of all creation only the human knows and consciously relates to God. This has support in the biblical account of the interactions between God and human in the early chapters of Genesis. In these chapters, and throughout the entire Bible, it is clear that "humans were not created merely to be a work of art, statues displaying God's creativity and wisdom, but to fulfil God's special intention for them. ${ }^{" 77}$ Erickson however raises two difficulties. ${ }^{78}$ The first has to do with the universality of the image. He questions how true this can be said of those who are in total indifference to God or even, hostile rebellion against God as being the image of God if the image is in relational terms. Another difficulty has to do with the question of what aspect of the human being enables him/her to relate to God. Relationship requires an ontological foundation. Without some essential content in two beings, there can be no relationship. The relational view does not give adequate attention to this ontological foundation for relationships.

\section{The Royal Functional View of the Imago Dei}

The royal functional view associates the image of God with the special functions that humans perform. ${ }^{79}$ The proponents of this perspective almost unanimously focus on the function of man as God's vice-regent who exercises dominion over creation. According to the functional view, image is neither something that belongs to man's makeup, nor in his experiencing of relationships. ${ }^{80}$ Instead, the image consists of something human does, the exercise of dominion over creation. This view contends therefore that "image" and "likeness" in Genesis refers to the task of exercising dominion over God's creation. Middleton explains this view further, "on this reading, the imago Dei designates the royal office of calling of human beings as God's representatives and agents in the world, granted authorized power to share in God's rule or administration of the earth's resources and creatures." ${ }^{11}$ The focus of this view is human's responsibility to exercise dominion over the earth. Contemporary representatives of this view, according to Erickson, include C.G. Berkouwer, Leonard Verduin, Norman Snaith, and Sigmund Mowinckel. ${ }^{82}$

The functional view has support in the fact that the creation of humanity is closely followed by the command to have dominion over the earth (Gen. 1:28). It rightly points to the close connection between being created in the image of God and having dominion over other creation (see also Psalm 8). However, it raises the question as to what connection there is between the image of God and man's dominion. Clines argues that although "man's dominion over the animals cannot be definitive of the image ... since dominion is so immediate and necessary a consequence of the image, it loses the character of a mere derivative of the image and virtually becomes a constitutive part of the image itself." ${ }^{33}$ Thus for Clines the image is not a matter of dominion being either definitive or a consequence of the image, but rather both.

Contrary to this view, it seems from Gen. 1:26-28 that who man is and what man does are two distinct things. In the spirit of agreement, Erickson points out that the use of the two expressions "Let us make man in our image, in our likeness" and "let them rule" seem to distinguish the image of God from the practice of dominion. The practice of dominion is to be rightly considered as the consequence of the image but not the image itself. ${ }^{84}$ Equating the image of God with the exercise of dominion is not supported by Scripture. The two are related, but separate.

\footnotetext{
73 Erickson, Christian Theology, 524.

74 Karl Barth, Church Dogmatics: A Selection with Introduction by Helmut Gollwitzer (Louisville, KY: Westminster John Knox Press, 1994), 187-88.

75 Barth, Church Dogmatics, 202.

76 Erickson, Christian Theology, 524

7 Erickson, Christian Theology, 529.

What follows is gleaned from Erickson, Christian Theology, 530.

Ibid.,527.

Ibid.

Middleton as cited in Tarus "Imago Dei in Christian Theology", 22.

Erickson, Christian Theology, 528-529.

Clines as cited in Kenneth M. Gardoski, “The Imago Dei Revisited” in The Journal of Ministry \& Theology Vol. 11 No. 2 (2007): 5-37, 14.

4 Erickson, Christian Theology, 531.
} 


\section{A Holistic Perspective of the Imago Dei}

Despite the paucity of biblical data on the image of God, and the difficulty associated with the above views, we may deduce five basic parameters. ${ }^{85}$ First, creation in the image of God is applicable to every person regardless of status in life, health condition, age, race, sex etc. Gen. 1:27 applies it to both male and female, Gen. 9:6 and James 3:9 use the expression generically for all humans. There is no scriptural evidence that the image of God varies from person to person. Therefore, superior in natural endowments such as intelligence must not be equated with higher presence of God's image. Second, being created in the image of God requires being God-like in some unspecified ways. The Hebrew words for image and likeness as well as their Greek equivalents are not very specific in their meanings. No statement in scripture limits the image to certain human activities, conditions or situations. The image refers to what human is rather than what humans do or has. It is something in the very nature of human, in the way in which they were made. Third, the imago Dei forms the basis for human uniqueness and dignity. It is the characteristic that distinguishes humans from other creatures. Fourth, the image of God in human was not completely lost after the fall of humanity. Humans were created as God's image, his representatives on earth. After the fall, humans were still God's image, his representatives on earth. The prohibition against murder in Genesis 9:6 also appeals to the fact that humans are the image of God. The punishment for the murder of a person is death because people are God's image. It is obvious that, despite the fall, humans are still the image of God. This means that the image of God is not something accidental or external to human nature. Fifth, the image of God in human has an eschatological dimension. It will be fully restored in Christ in the future kingdom of God.

\section{Implications of the Study for an African Context}

Obviously, the doctrine of imago Dei has serious implications for the euthanasia debate within the African religiocultural setting. In Africa euthanasia is illegal. Assisted suicide is legal and permitted in Switzerland and in three states in the United States of America-Washington, Oregon and Montana. ${ }^{86}$ Like African countries, some western countries such as Australia, Israel, New Zealand, Norway, Turkey, and the United Kingdom all reject and do not permit the practice and act of euthanasia. ${ }^{87}$ Death and dying forms an integral part of their everyday experience of every human society. The Akan of Ghana underline their belief in the inevitability of death when they say, owuo atwedec baako nforo ("Everyone will climb the lather of death"). Africans have the concept of "good death" and "bad death." ${ }^{88} \mathrm{An}$ individuals who lived a decent life and died naturally is said to have has a good death, (Akan: owupa), while the one who died through an unnatural cause such as accidents, suicide or a woman who dies during childbirth is considered to have had a bad death (Akan:atəfo wuo). ${ }^{89}$ Dying a good death is a requirement for one to qualify as an ancestor. Once a person has lived a decent life is about to die at a ripe age, no attempts are made to artificially prolong his or her life.

According to the African belief system, the soul of the departed person passes to the world of the ancestral spirits where it continues to live. For this reason, Africans refers to the souls of dead persons as the living dead. However, the soul of a person who has committed suicide is doomed and becomes an evil spirit. Such a person did not die a "good death." Thus, for the Africans, what is highly debatable is not the whether one will die or not but the appropriate human response to the controllable state or condition under which the event of a human death takes place.

While euthanasia is illegal in Africa, it sometimes occurs where people ask others to assist them to die due to incurable painful disease. There are cases where family members request physicians to withhold care for their relatives due to non-availability of funds to sustain such treatment. One must however note that, these forms of assisted deaths that occur in Africa are motivated mainly by lack of funds and inadequacy of health care facilities rather than the desire to relief a patient from suffering. ${ }^{90}$ Owusu-Dapaa therefore rightly observes that, "apart from poverty, traditional cultural values of African societies consider non-natural death as a taboo and ignominy to the victim and his family. ${ }^{91}$ There is also the tradition where the elderly refuse going to hospital for treated when they become sick because of the belief that dying in "foreign hands" is not a good death. ${ }^{92}$ This tradition which, according to Kunhiyop, is common among the Bajju of Nigeria underscores Africans' preference to die in the hands of their own relatives than other ("foreign") people.

85 Gleaned from Daniel L. Akin ed.), A Theology for the Church (Nashville: B\&H Academic, 2007) 352-3.

86 Penney Lewis, "Assisted dying: What does the law in different countries say?" (2015).

Accessed at https://www.bbc.com/news/world-34445715 (28th May, 2020)

87 Priscilla Rockman, "Euthanasia: A study of its Origin, Forms and Aspects" (Unpublished Thesis: University of Gavle, 2012), 11. Accessed from https://pdfs.semanticscholar.org/8977/5e2821c538b46989456e8b8f645dab3476b3.pdf

88 K. Agyemang, "The Impact of new medical technology upon attitudes towards euthanasia among Akans, Cultural Heritage and Contemporary Change," accessed at http://www.crvp.org/book/Series02/II-5/chapter_ix.htm [23rd August, 2015)

89 C. Seale and S. van der Geest, "Good and bad death: Introduction" in Social Science \& Medicine 59 (5) (2004): 883-886, 885.

90 Agyemang, "The Impact of new medical technology".

91 E. Owusu-Dapaa, "Euthanasia, Assisted Dying and the Right to Die in Ghana: A Socio- Legal Analysis" in Med Law 32(4) (2013): 587-600, $1-2$.

92 Kunhiyop, African Christian Ethics, 347. 
In the olden days, malformed babies were also killed, for example by giving them akpeteshie (locally manufactured strong alcohol) to drink or by taking them to the forest or abandoning them on river banks to be devoured by wild animals. The belief that these children are incarnated spirits with the aim of tormenting humans is the reason for killing them. ${ }^{93}$ In some communities (in Benin and Nigeria), twins were also considered evil and were therefore killed. ${ }^{94}$ More so, aged people, who felt they had become a burden, could ask their relatives to end their lives through drowning,

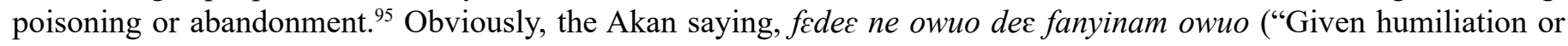
indignity versus death, the Akan prefer death"), condones euthanasia.

The Akan belief in nkrabea is very strong and "destiny not only transcends all human ability to resist it, but any human attempt to resist it is regarded as evil and self-denigrating." ${ }^{6}$ Therefore, the Akan's attitude to the course of destiny — to any act of nature or of God — is a passive one. ${ }^{97} \mathrm{In}$ view of this, "there exists a moral tension between humble acceptance of one's destiny and noble preference for death over a life of indignity and humiliation." suicide is acknowledged through it is also regarded as undermining the honor and dignity of the victim's family. Given this tension, one may conclude that the African may not be so much trouble in the case of passive euthanasia as he or she will in the case of another person being actively involved in the death of another. From Zimbabwe, Munyaradzi Mawere reports that, the Shona hold the view that "choosing death in whatever circumstances is considered harmful, destructive and a loss not only to the bearer of life but to family, friends and the community to which the one whose life is terminated is a member." 99 For this reason, "traditionalists in Shona society agree with Aquinas that euthanasia is morally wrong." ${ }^{100}$ Certainly, the legalization of euthanasia on the African soil cannot be acceptable.

The discussions in the preceding paragraphs ended on the note that euthanasia is not ethically, culturally and religiously acceptable in Africa. With that as a background the study now moves on to consider what implications the doctrine of imago Dei has on the subject of euthanasia. The doctrine of imago Dei implies that human life has an intrinsic value, not just a conditional one. The intrinsic value of humanity is universally shared irrespective of our race, ethnicity, age, health condition or culture. Therefore, "human life is not only an instrumental good, a necessary precondition of thinking or doing, but a basic good, a fundamental basis of human flourishing." ${ }^{101}$ The researcher believes that the value and sacredness of life does not depend on its usefulness but on the fact that human being carries the image of God. One can therefore agree with the idea that "As an image of God, every person has a dignity which must not be subordinated to any other purpose and which must be protected." ${ }^{02}$ The Bible prohibits the killing of innocent human beings (see for example, Exod. 20:13, Deut. 5:17) and as such regardless of a person's condition, deliberately taking his or her life is a murder and detestable to God.

The argument for euthanasia tends to regard human beings as things that may or may not have value. It is argued that when life is devoid of its human quality, it ceases to be worth living for and the person involved must not be allowed to live any longer. When there is suffering, pain and terminal illness or sickness that offers no real hope for full recovery, a person's quality of life is so low that he/she is better off dead than alive.

Contrary to this thought, the doctrine of imago Dei implies that every human being has supreme value despite the quality of their life. Using the quality of life consideration in determining who should be allowed or helped to die would mean some persons in society who are not necessarily under excruciating pain, or terminally ill could involuntarily be killed. These would include those with dementia, extremely disabled persons (who depend on others for all help), children born with extreme deformities, and social invalids. The doctrine of imago Dei means that all humans, no matter their state, have some value to God. Every human is precious to God. "Thus, the Christian attitude toward human life can only be one of reverence enjoined by the whole of the Decalogue (not only by the sixth Commandment) and confirmed by the incarnation - which is extended to every individual from the moment of his conception to extreme old age." 103

The doctrine of imago Dei also implies that there is no price tag on human life. For this reason, one cannot tell how much is too much to preserve human life if possible. It is therefore wrong to suggest that life must be protected

\footnotetext{
93 Ibid.

94 Ibid.

95 Ibid.

96 Helen Lauer (ed.), Ghana: Changing Values/Changing Technologies: Ghanaian Philosophical Studies, II in Cultural Heritage and Contemporary Change. Series Ii, Africa, Vol. 5 (Np: Council for Research in Values 1999), 204.

${ }_{97}$ Lauer (ed.), Ghana: Changing Values, 204.

98 Lauer (ed.), Ghana: Changing Values, 204.

99 Munyaradzi Mawere, "The Shona Conception of Euthanasia: A Quest to Depart from Zimbabwe Tradition," The Journal of Pan African Studies. Vol. 3. No.4 (2009):101-116, 105.

100 Mawere, "The Shona Conception of Euthanasia," 105.

101 Keown, Euthanasia, Ethics and Public Policy, 41.

102 Hans-Georg Ziebertz and Francesco Zaccaria (eds.), Euthanasia, Abortion, Death Penalty and Religion - The Right to Life and its Limitations (Gewerbestrasse: Springer, 2019), 1.

103 As quoted by Trevor J. Major, “Life: Sanctity or Quality?” in Journal of Biblical Ethics in Medicine, Vol. 3, No. 4 (nd): $19-20,19$.
} 
and preserved only when it can be afforded. ${ }^{104}$ One can agree with Geisler that the value of human life (no matter the person's condition) cannot be calculated; that is, human life is priceless. ${ }^{105}$ This position seems to echo Jesus' teaching that it profits no one to have the whole world but his/her soul (Mark 8:36). The main argument from the doctrine of imago Dei is that the decision to sponsor the treatment of a person should not be determined by the perceived value of the person's life. Such evaluation is not the prerogative of human but of God.

The researcher agrees with the contention that true autonomy should be the freedom to be and act in accordance with God's will, not contrary to God's will. Consequently, if it is ethically wrong to actively murder, then it is equally wrong for a person to choose to be murdered regardless of his or her condition. One who, in a state of despair, chooses to die is still guilty of murder. A person's right to live should therefore not depend on the person himself or herself wanting to live.

Finally, though everyone has the right to life, this right depends on God's will and purpose for one's life because life is a gift given by God to humans to be stewards of it. One may compare this gift to the talents that the master gave to his servants and from which he expects them to invest and gain proper return as depicted in Jesus' parable in Matthew 25:14-30.

\section{CONCLUSION}

The doctrine of imago Dei implies that every single human being, no matter how much the image of God is marred by sin, or illness, or weakness, or age, or any other disability, still has the status of being in God's image and therefore must be treated with the dignity and respect that is due to God's image-bearers. Human dignity and value is not dependent upon the circumstances that a person finds him- or herself in. The circumstances one finds oneself in are not a sufficient reasons for a person to be helped to die. Human life must be dignified because humans carry the image of God. The decision on what life is worth living and what life is not is of God, not human. In the eyes of God even people who are terminally ill, people suffering from intolerable pain, people in Persistent Vegetative State, people requiring life support machines, and others in similar conditions, are still human beings with full human dignity and value despite their ailing situation. This paper also found that legalizing euthanasia has the tendency of leading to coercion, loss of autonomy; reduction of efforts in diagnosis, treatment, and care. Poor decision-making by the sufferer or care-givers may lead to inappropriate euthanasia; diagnostic errors and medical advances. Based on these findings the paper contends that even though the preservation of physical life is not the ultimate goal of Christianity (since physical death is inevitable), human life should not be shortened deliberately for any reason. Therefore, it is morally wrong to take anybody's life under any circumstance.

\section{BIBLIOGRAPHY}

Agyemang, K. "The Impact of new medical technology upon attitudes towards euthanasia among Akans, Cultural Heritage and Contemporary Change" http://www.crvp.org/book/Series02/II-5/chapter_ix.htm

Akin, Daniel L. ed. A Theology for the Church. Nashville: B\&H Academic, 2007.

Barth, Karl. Church Dogmatics: A Selection with Introduction by Helmut Gollwitzer. Louisville, KY: Westminster John Knox Press, 1994.

Beck, James R. and Demarest, Bruce. The Human Person in Theology and Psychology: A Biblical Anthropology for the Twenty-First Century. Grand Rapids: Kregel Publications, 2005.

Beckwith, Francis and Geisler, Norman L. Matters of Life and Death. Grand Rapids, MI: Baker Book House, 1991.

Berkhof, Louis. Systematic Theology. Edinburg: Banner of Truth, 2000.

Boaheng, Isaac. Exploring the Relationship Between Divine Sovereignty and Human Responsibility in Relation to God's Plan of Salvation. Master of Divinity Thesis, Trinity Theological Seminary, 2016.

Boudreau, J. Donald and Margaret A Somerville, “Euthanasia and Assisted Suicide: A Physician's and Ethicist's Perspectives" in Medicolegal and Bioethics 2014 (4): 1-12.

Chaiklin, Sharon and Hilda Wengrower. eds., The Art and Science of Dance/Movement Therapy: Life Is Dance 2nd edition. London: Routledge, 2016.

Cairns, David. The Image of God in Man. London: SCM, 1953.

Erickson, Millard J. Christian Theology. 2nd edition. Grand Rapids, MI: Bake Academic, 1998.

Gardoski, Kenneth M. "The Imago Dei Revisited" in The Journal of Ministry \& Theology Vol. 11 No. 2 (2007): 5-37.

Geisler, Norman L. Christian Ethics: Contemporary Issues and Option. Second edition. Grand Rapids: Baker Academic, 2010.

\footnotetext{
${ }^{104}$ Geisler, Christian Ethics, 168.

105 Ibid.
} 
Grudem, Wayne. Christian Ethics: An Introduction to Biblical Moral Reasoning (Wheaton, IL: Crossway, 2018

Henry, C. F. C. "Image of God" in Evangelical Dictionary of Theology (2nd Edition) edited by Walter A. Elwell. Grand Rapid, MI: Baker Publishing Group, 2001.

Lauer, Helen ed. Ghana: Changing Values/Changing Technologies: Ghanaian Philosophical Studies, II in Cultural Heritage and Contemporary Change. Series Ii, Africa, Vol. 5. Np: Council for Research in Values, 1999.

Lewis, Gordon R. and Demarest, Bruce A. Integrative Theology: Historical, Biblical, Systematic, Apologetic, Practical. Grand Rapids: Zondervan, 1996.

Humphry, Derek. Dying with Dignity: Understanding Euthanasia. New York: Carol Publishing Group, 1992. Johnstone, Megan-Jane. Bioethics: A Nursing Perspective. 2nd edition Australia: Southwood Press, 1994.

Lewis, Penney. "Assisted dying: What does the law in different countries say?" 2015. Accessed at https://www.bbc.com/news/world-34445715

Major, Trevor J. "Life: Sanctity or Quality?" in "Life: Sanctity or Quality?" in Journal of Biblical Ethics in Medicine. Vol. 3, No. 4 (nd): 19-20.http://bmei.org/wp-content/uploads/2017/07/major_life_sactity_or_quality.pdf

Manning, Michael. Euthanasia and Physician-Assisted Suicide: Killing or Caring? New York: Paulist Press, 1998.

Mawere, Munyaradzi. "The Shona Conception of Euthanasia: A Quest to Depart from Zimbabwe Tradition," The Journal of Pan African Studies. Vol.3. No.4 (2009):101-116.

Owusu-Dapaa, E. "Euthanasia, Assisted Dying and the Right to Die in Ghana: A Socio- Legal Analysis" in Med Law 32(4) (2013): 587-600.

Pakhu, Joseph. "Debate on Euthanasia (Pros and Cons)". Unpublished MTh Thesis: Universidade Católica Portuguesa, 2015.

Raymond G. Frey and C. H. Wellman (eds.), A Companion to Applied Ethics. Malden: Blackwell Publishing Ltd., 2003.

Rockman, Priscilla. "Euthanasia: A study of its Origin, Forms and Aspects". Unpublished Thesis: University of Gavle, 2012. https://pdfs.semanticscholar.org/8977/5e2821c538b46989456e8b8f645dab3476b3.pdf

Sakali, Ferdinand. "The Contemporary Euthanasia Debate In The Light of African World View and Ethics" in SEGi Review Vol. 6, (2013): 5-15.

Seale, C. and S. van der Geest, "Good and bad death: Introduction" in Social Science \& Medicine 59 (5) (2004): 883-886.

Sproul, Robert C. Chosen by God. Illinois: Tyndale Publishers, Inc., 1986.

Tarus, David. "Imago Dei in Christian Theology: The Various Approaches" Online International Journal of Arts and Humanities Volume 5 (2016) 18-25.

Torr, James D. ed. Euthanasia: Opposing Viewpoints. California: Greenhaven Press, Inc., 2000.

University of Western Ontario, The Canadian Journal of Law and Jurisprudence, Volumes 1-2. Ontario: University of Western Ontario, 1989.

von Rad, Gerhard. Genesis. Philadelphia: Westminster Press, 1972.

World Health Organization, Planning and Implementing Palliative Care Services: A Guide for Programme Managers. Geneva: World Health Organization Press, 2016.

Ziebertz, Hans-Georg and Francesco Zaccaria eds. Euthanasia, Abortion, Death Penalty and Religion - The Right to Life and its Limitations. Gewerbestrasse: Springer, 2019. 